\title{
MODELLING OF COSTS OF CAPITAL IN SLOVAK ENTERPRISES
}

\author{
Katarina Valaskova ${ }^{1, a, *}$, Elena Gregova ${ }^{2, b}$ \\ ${ }^{1}$ University of Zilina, Faculty of Operation and Economics of Transport and Communications, \\ Department of Economics, University of Zilina, Univerzitna 1, 01026 Žililna, Slovakia \\ ${ }^{2}$ University of Zilina, Faculty of Operation and Economics of Transport and Communications, \\ Department of Economics, University of Zilina, Univerzitna 1, 01026 Žililna, Slovakia \\ akatarina.valaskova@fpedas.uniza.sk, belena.gregova@fpedas.uniza.sk \\ *Corresponding author
}

Cite as: Valaskova, K., Gregova, E. (2017). Modelling of costs of capital in Slovak enterprises, Ekonomicko-manazerske spektrum, 11(2), 76-89.

Available at: dx.doi.org/10.26552/ems.2017.2.76-89

\begin{abstract}
The paper deals with the issue of the corporate cost of capital and its calculation. The main aim of the article is to identify significant factors affecting the value of the costs of capital in the Slovak Republic and to form a model that would allow Slovak companies to compute the value of the costs of capital. We identify the main parameters of our potential model considering six relevant studies that were performed in foreign countries, accepting only those determinants that were applicable in Slovak economic conditions. Then the values of selected parameters are calculated for 32,127 companies of our database and the weighted average costs of capital of the entities in the database, considering the calculation of costs of equity using the CAPM model modified for non-American markets and costs of debt. We use the regression analysis to compute the statistical characteristics of the econometric model. We found out that the significant parameters to be included in the model are levered beta, value of equity, leverage, corporate size, long-term debt capital to total assets, return on assets and on investments, legal form, SK NACE and region. Using the significance F-test and Pearson chisquare test we can claim, that there is a statistically significant relationship between the corporate costs of capital and the legal form and SK NACE classification and we can conclude that there is a statistical significance of the constructed model of the costs of capital quantification. This model can be used to compute the costs of capital of the individual companies in the Slovak economic conditions.
\end{abstract}

Keywords: capital, cost of capital, cost of equity, cost of debt, regression

JEL Classification: G31, G32

\section{Introduction}

The decision making process connected with the financing of an enterprise have a considerable significance in a corporate governance and in the future profitable development. The capital structure and its adjustment can be influenced by many internal and external capital structure determinants. Internal factors can be managed by a company, but macroeconomic factors cannot be controlled. (Mokhova \& Zinec, 2013) The financial decision set by management is very important in determining the optimal capital structure. The company management has to set their capital structure in a way to maximize the company value. 
However, entities have a different level of leverage and managers try to achieve the best set to attain an optimal capital structure. (Salim et al., 2012)

In developed market economies, the issue of valuation of enterprises is still topical, particularly as a result of certain development trends in the world economy, which created the need for an effective deployment of large amount of available capital. (Kislingerova, 2001) The issue of valuation of capital in the Slovak Republic began to reappear in connection with the transformation of the economy and in particular with the transformation of ownership in enterprises. After forty years of a mandatory administrative management not only the book value was important but also the market value started to be used, mainly due to privatization when the market value was a crucial indicator for investors, owners (shareholders) and creditors, mostly banks. (Kislingerova, 2001) And, just at the moment of an increased interest in understanding the value of a company it became apparent that in our conditions there is a great lack of information in terms of valuation, both in literature and in practice.

The paper is divided into four main parts. Literature Review is focused on the most important researches being done in this field since the introduction of this theory by Modigliani and Miller in 1958. Second part is devoted to aims and methodology of the paper. The Results part is divided into two subchapters, containing the calculations of weighted costs of capital (WACC) of entities in the database and hypotheses testing. In Discussion we compare the results of international empirical studies with the results of our model.

\section{Literature review}

Financial management in a company is a decision process subject to achievement of the main goal of the company, that is its value maximization. Estimation of the cost of capital is of great significance in this area. (Michalak, 2016) The cost of capital affects the key decisions of the board concerning the scale of investment undertakings, determination of the target, demanded amount and pace of capital growth, shaping of optimal capital structure and other areas of financial management in a company such as capital budgeting, processes of takeovers and fusions etc. Decisions about company financing became an important issue since Modigliani and Miller introduced their theory in 1958. They concluded, on the basis of some unreal conditions (e.g. zero taxes and no bankruptcy costs), that financing decisions would not affect the value of the company. Costs of capital are very important trading and financial instruments, but also a determinant of an economic growth of the country, as they enlarge or reduce a set of investors and potential investment projects. They determine the balance between investments, consumption and economic growth at the macroeconomic level. (Ogier et al., 2004) Damodaran (2006) claims that costs of capital are the combined cost of financing that reflect the costs of debt and equity and their relative weights in the financial structure. According to Fernandez (2002) costs of capital are determined by the capital market and they are closely related to the degree of risk investors. Costs of capital are often considered to be the minimum yield or the minimum expected rate of return that an investor would accept from a particular investment. The rate of return may be the same, higher or lower than the total company costs of capital, depending on the level of risk associated with the investment. The riskier the investment, the higher the reward for running the risk. The company has higher costs of equity. Not every risk is the same. A rational investor seeks an optimally diversified portfolio, and therefore it requires a compensation only for that portion of risk that is associated with the portfolio. (Ogier et al., 2004) In this context, an investor is every person who borrows money to a company and expects a certain yield. Provision of financial resources to the company has various forms, for example the purchase of common shares or bonds. The higher the yield required by investors, the higher 
the costs of capital of the company. One of the reasons why companies calculate the costs of capital is the estimation of the minimum discount rate used for the assessment of proposed capital expenditures (projects). The purpose of this analysis is to decide which of the projects should the company realize.

Modigliani and Miller have inspired many financial experts and scientists who focused on the identification of corporate capital structure determinants. And so we try to summarize some of the best known theories of optimal capital structure. Trade- off theory arose as a result of discussions on the Modigliani-Miller theorem and it tries to show, that company will borrow up to the point, where the marginal value of the tax reduction or tax shield on the interest paid for the contracted loans, will be balanced by an increase in the present value of the bankruptcy costs. (Myers, 2001) The development of the classic version of the trade-off theory was done by Kraus and Litzenberger (1973), who proved that the market value of a company with debt is the same as the market value of a company which does not have any debt in its capital structure plus the present value of the tax shield minus the present value of the bankruptcy costs. Pecking order theory was released by Myers and Majluf (1984) and it shows that because of the information asymmetry among investors, managers and shareholders companies prefer to finance their activities with internal resources on the first place, with the debt on the second place and then using the equity. The base of the agency theory lies on the presumption that managers and shareholders have different interests and therefore, in spite of the fact that managers should act on behalf of the shareholders, it often happens that managers pursue their personal benefits. (Jensen \& Meckling, 1976) Authors of this theory identified the agency costs that should consist of expenses spent by directors in monitoring their managers, the expenses related to the obligations of the agents and other residual losses. They also named the types of conflicts of interests that are connected with the agency costs: conflicts between shareholders and managers and conflicts between shareholders and creditors, which arise when the level of debt rises and in case of default shareholders can obtain benefits on behalf of the creditors. (Serghiescu \& Vaidean, 2014) Market timing theory argues that the capital structure of companies whose securities are traded on an exchange can be affected by some conditions of the capital market and some other conditions of the country. (Memon et al., 2014) Trying to be in synchronization with the market means that companies issue shares at a high price and then try to redeem or buyback these stocks at a lower price. The beneficiaries of this practice are the existing shareholders and the managers who pursue the interests of the investors, are expected to synchronize with the market. (Baker \& Wurgler, 2002)

As we mentioned before, there is no universal theory of capital structure, and no reason to expect one. Myers (2001) says that there are useful conditional theories. Each factor could be dominant for some company or in some circumstances but unimportant in others. (Murray \& Vidhan, 2003) Much of the literature on capital structure is focused on the study of balanced panels of companies, for instance Titman and Wessels (1988), and Shyam-Sunder and Myers (1999). It is now well understood that studying balanced panels may induce survivorship bias. More recent studies, such as Hovakimian et al. (2001), Fama and French (2002) and Frank and Goyal (2003), typically employ unbalanced panels of companies. Modigliani and Miller's theory has inspired many financial experts and scientists who focused on the identification of corporate capital structure determinants. For example, Titman and Wessels (1988) for US, Rajan and Zingales (1995) for G-7, Drobetz and Fix (2005) for Switzerland, and Vivani (2008) for France. The situation in Europe is searched by Amaral et al. (2010), Voth (2003, 2002). Current research in this field is focused on the most accurate estimation of costs of capital (Levi and Welch (2017)), influence of taxation (Creedy \& Gemmell, 2017), the effect of information (Johnstone, 2016; Plumlee, 2016; Viviani, 2008) and firm growth (Dutta \& Nezlobin, 2017) 
and the link between corporate social performance and costs of capital (Suto \& Tekehara, 2017). Lambert et al. (2007 and 2012) suggested a connection between the quality of information and the cost of capital; the impact of a change to the trading system on the costs of capital is described by Chelley-Steeley and Lambertides (2014). Olson and Pagano (2017) develop a new way to measure the cost of capital, called the empirical average cost of capital, which is consistent with existing methods of calculating the weighted average cost of capital, but uses information from the firm's financial statements and requires fewer and less subjective inputs. However, when deciding about the optimal capital structure we are talking about identifying the optimal ratio of equity and debt. Generally speaking, the optimal capital structure minimizes the value of the weighted average cost of capital and maximizes the value of the company, debt plus equity. (Fernandez, 2013) One of the most important factors that should help financial managers to build the optimal capital structure is the cost of capital.

\section{Aims and methodology of the research}

The main aim of the paper is to identify the significant factors influencing the costs of capital and to create the econometric model to be able to calculate the costs of capital in Slovak economic conditions. In connection with this main aim, we also define the secondary objectives - to define the capital and its components as well as the optimal capital structure. Except for basic research methods (analysis, synthesis, induction, deduction, scientific observation and description and explanation) we used the method of comparison which is an important factor also in the process of optimal capital structure, i.e. the ratio of equity and debt. We compare the costs of capital of enterprises depending on the legal form, the position in the various regions of Slovakia and the category of economic activities according to the SK NACE classification.

The algorithm of processing of our research consists of the following steps:

1. Study of international scientific surveys and researches dealing with the formation of models to quantify the costs of capital in order to identify the determinants of the costs of capital,

2. Taking the experience from abroad into account, choose significant factors affecting the costs of capital, which can be identified in the Slovak economic conditions,

3. Determination of the significance of each factor describing the amount of the costs of capital and of the decision on their statistical significance within the constructed model,

4. Statement of the dependence of the amount of costs of capital on various parameters

5. In connection with the main and partial objectives of the paper, we define the following hypotheses at the significance level $\alpha=0.05$ :

Hypothesis 1: There is a statistical significance of the constructed model of the costs of capital quantification.

Hypothesis 2: There is a statistically significant relationship between the costs of capital of business entities depending on the legal form.

Hypothesis 3: There is a statistically significant relationship between the costs of capital of business entities depending on the SK NACE classification.

The parameter, costs of capital, is very important business tool and financial instrument but also the determinant of a country economic growth because it can increase or decrease the number of investors and investment projects. Costs of capital calculation using the regression analysis has become a very interesting topic and many financial specialists have tried to create a regression model. They identify some determinants that should influence the costs of capital and then examine the statistical significance of these determinants. In our article we analyse six of these models: conditional conservatism and cost of capital (Garcia et al., 2009), toward an 
ex ante cost of capital (Gebhardt et al., 1999), corporate governance and the costs of equity capital (Ashbaugh et al., 2004), costs of capital and earnings transparency (Barth et al., 2013), estimating expected costs of equity capital: a theory based approach (Botosan \& Plumlee, 2001) and implied costs of equity capital and corporate governance practices (Byun et al., 2008). Based on the mentioned studies we selected the parameters that could be usable in the Slovak economic conditions. Approaches of authors to the issue of the costs of capital calculation are very individual, depending on the purpose and other conditions of the model. This is the reason of a large variety of parameters. It is clear that none of the mentioned models can be directly applied in the Slovak conditions. However, we can identify determinants which were used in more models or which are applicable in our economic conditions. We use these parameters: indebtedness of a company (leverage), size of a company, beta factor, value of equity, ratio of long-term debt capital to total assets (DBTA), ROA - we also use ROE and ROI - which are the ratios often used in our economic conditions and Altman Z-score. Subsequently we add also some qualitative parameters into the model: legal form of a company, region and SK NACE classification.

\section{Results}

We use the database of Slovak companies, which includes balance sheets and profit and loss accounts of entities whose financial statements for 2014 were published in the central register of the Financial Administration of the Slovak Republic. From the original database, we did not use those entities, which had negative assets and equity and those where the demonimator in the parameter was zero. After the elimination, we had 32,127 financial statements, which can be all described by the qualitative parameters - district, legal form and SK NACE classificationwhich enables to examine the impact of these variables on the value of the total costs of capital. The frequency of entities in our sample is very evenly distributed (in terms of geographic location) and is about 10\% (excluding Bratislava region). Regarding the average value of the costs of capital within each region, we did not record any significant difference and any significant deviation from the average. The costs of capital were $8 \%$ in Zilina and Trnava up to $8.22 \%$ in the region of Banska Bystrica. We applied the model to the dataset that consists of the data from the financial statements of the 32,127 Slovak companies for the year 2014. They represent the companies from all regions of the Slovak Republic, from all legal forms and from many categories of the economic activities.

\subsection{Calculation of WACC of the entities in the database}

Our model consists of several independent variables and a single dependent variable, which is the cost of capital of entities. However, the costs of equity are calculated using the CAPM model modified for non- American markets (CAPM model with country risk premium) and the costs of debt are determined using the methodology od Damodaran (2006) which is used to calculate risk free rate and risk premium.

\section{Costs of equity}

To calculate costs of equity, the CAPM model is the most frequently used. The risk free interest rate presents the rate of the return of the assets that do not carry any risk. Despite the fact that this assumption is only theoretical, we can use, as an alternative, government securities, which are usually related to the lowest risk level. In our case, there are Slovak government bonds. To meet the ideal requirements, the security should have similar maturity as the capital. But, it is often impossible as we do not know the exact capital structure of individual companies. However, we can distinguish the long-term and the short-term capital, and therefore we can use 
two types of risk-free rates. We use the rate of return of Slovak government bonds for the longterm capital (Table 1). As we do not know exactly which maturity is the most appropriate, we average the rates of return of bonds issued in three years $(2015,2014,2013)$. The average riskfree rate of return for long-term capital is $2.68 \%$.

Table 1: Rate of return of selected government bonds

\begin{tabular}{lllllll}
\hline $\begin{array}{l}\text { Issue } \\
\text { number }\end{array}$ & ISIN & Date of issue & $\begin{array}{l}\text { Date of } \\
\text { maturity }\end{array}$ & $\begin{array}{l}\text { Maturity in } \\
\text { years }\end{array}$ & $\begin{array}{l}\text { Nominal value } \\
(€ / \text { pcs })\end{array}$ & $\begin{array}{l}\text { Rate of } \\
\text { return in } \% \\
\text { p.a. }\end{array}$ \\
\hline 224 & SK4120008954 & 8.2 .2013 & 8.2 .2033 & 20 & 1 & 3.88 \\
225 & SK4120009044 & 28.2 .2013 & 28.2 .2023 & 10 & 1 & 3.00 \\
226 & SK4120009234 & 28.5 .2013 & 28.11 .2018 & 5.5 & 1 & 1.50 \\
227 & SK4120009762 & 16.1 .2014 & 16.1 .2029 & 15 & 1 & 3.63 \\
228 & SK4120010430 & 22.1 .2015 & 21.1 .2027 & 12 & 1 & 1.38 \\
\hline
\end{tabular}

Source: Own elaboration based on www.ardal.sk

Considering the short-term capital, it is recommended to use Euribor ${ }^{\circledR}$ rate, which is an interbank reference rate within the Economic and Monetary Union, which was introduced in 1999. It is the rate, at which the euro-term deposits are offered by one bank to another bank in the interbank market. An again, an average of more selected rates was calculated (Table 2), which gives a rate of $0.197 \%$.

Table 2: Interbank reference rate Euribor

\begin{tabular}{llll}
\hline Maturity & Rate in $\%$ & Maturity & Rate in \% \\
\hline 1 week & -0.042 & 6 months & 0.107 \\
2 weeks & -0.032 & 7 months & 0.381 \\
3 weeks & 0.120 & 8 months & 0.418 \\
1 month & -0.008 & 9 months & 0.158 \\
2 months & 0.015 & 10 months & 0.489 \\
3 months & 0.036 & 11 months & 0.519 \\
4 months & 0.267 & 12 months & 0.225 \\
5 months & 0.309 & Average & $\mathbf{0 . 1 9 7}$ \\
\hline
\end{tabular}

Source: Own elaboration based on http://www.emmi-benchmarks.eu/euribor-org/euribor-rates.html

The market risk premium reflects the difference between the rate of return of a risk-free investment and the rate of return of an investment in the entire market, but we have to take the risk of the country into account. Professor Damodaran, on his website, regularly updates the values of equity risk premiums, which are divided into the values for the US market (Implied Equity Risk Premiums - United States) and for other markets (Risk Premiums for Other Markets). For the calculation we need the market risk premium of Slovakia (Table 3), which can be directly found in the file for other (non-US) markets. However, it is also possible to derive it from the US data but we need to know the differences between the rating of US and Slovak government securities (accepted is only the rating of Moody`s and Standard and Poor`s agencies).

Table 3: Calculation of market risk premium

\begin{tabular}{ll}
\hline Market risk premium USA (S\&P 500) & $5.75 \%$ \\
Rating of the USA (Moody`s) & Aaa \\
Rating of Slovakia (Moody`s) & A2 \\
Default spread of a country calculated from ratings & $0.85 \%$ \\
Volatility factor of stock markets & 1.5 \\
Country risk premium & $1.28 \%(=0.85 * 1.5)$ \\
\hline Market risk premium of Slovakia & $\mathbf{7 . 0 3 \%}(=\mathbf{5 . 7 5 + 1 . 2 8})$ \\
\hline
\end{tabular}


The beta coefficient is a measure of risk of individual securities to the risk of the capital market. It reflects the systematic market risk, assuming that a rational investor creates a portfolio, which can diversify the risk. The higher the value of the beta coefficient, the more sensitive the asset about the market changes. In the CAPM model, we need to know the beta factor of a specific sector. Our database of business entities contains also the information about the classification of economic activities (SK NACE). And so, we assign a sector, which corresponds to prof. Damodaran sectoral classification, to each business entity. We used the data for Europe, because this category includes all member entities of the European Union. But, this is the information about the unlevered beta, which means that the company has no debt. For the purposes of our model, we need to calculate the levered beta factor, which takes the debt capital in the capital structure of the company into account. For this calculation, we use Hamada formula (1), which was applied to recalculate the beta factor for all companies the database:

$$
\beta_{L}=\beta_{u} \cdot \frac{D(1-d)}{E}
$$

where $\quad B_{l}$ is the levered beta,

$B_{u}$ is the unlevered beta,

$D$ presents the value of the debt,

$d$ is for the income tax rate of legal persons,

$E$ is the value of equity.

Table 4: Specific risk premium (premium for the company size)

\begin{tabular}{lll}
\hline Decile & Value of the property in euros & $\begin{array}{l}\text { Specific risk } \\
\text { premium in } \%\end{array}$ \\
\hline 1 & 917,008 and more & -0.36 \\
2 & $309,528-917,008$ & 0.65 \\
3 & $143,704-309,528$ & 0.81 \\
4 & $75,454-143,704$ & 1.03 \\
5 & $42,480-75,454$ & 1.45 \\
6 & $24,392-42,480$ & 1.67 \\
7 & $13,188-24,392$ & 1.62 \\
8 & $6,769-13,188$ & 2.28 \\
9 & $4,502-6,769$ & 2,79 \\
10 & 4,502 and less & 6,27 \\
\hline
\end{tabular}

Source: Own elaboration based on http://www.znaleckyportal.cz/

A specific risk premium is most often the premium for the company size, because larger companies are generally considered less risky than smaller ones. The size premium is determined based on the market capitalization and is annually released by companies Morningstar/ Ibbotson or Duff \& Phelps. Ibbotson divides specific values of the market capitalization into deciles and each is assigned by a particular premium. For the purposes of our calculation, we were inspired by this procedure, and therefore we use the same values of the size premiums, but we change the range of intervals according to the property size of businesses in our database (Table 4). These were divided into ten groups and each decile was assigned by the specific relevant premium (this practice is also used by Czech experts).

\section{Costs of debt}

To calculate the costs of debt, we use the general procedure when the risk premium of debt is added to the level of the risk free rate (2):

$$
n_{C K}=r_{f}+R P_{C K}
$$


where $\quad n_{c k}$ are the costs of debt, $r_{f}$ is the risk free return rate, $R P_{C K}$ is for risk premium of debt.

The risk premium was determined by the variable times interest earned ratio (EBIT/ debit interests), which was calculated for all companies in our database. Based on the times interest earned ratio, each company was assigned by the rating and the associated value of risk premium (which was again found on the website of prof. Damodaran who divides risk premiums depending on the type of the company - large, small, risky and providing financial services). Once all the mentioned partial calculations were done we could calculate the weighted average cost of capital, giving us the dependent variable $\mathrm{Y}$ of our potential model to calculate the cost of capital of business entities in the Slovak economic conditions.

Regression model consists of one dependent variable (which is the value of the costs of capital) and several explanatory variables (those are the selected determinants). For the calculations we used the Data analysis in Excel (more specifically the function Regression).

Then we had to find out whether all parameters of our model are statistically significant or not. For each tested coefficient we define a null hypothesis (H0: The coefficient is not statistically significant) and an alternative hypothesis (H1: The coefficient is statistically significant). After the application of the regression function we found out that all parameters are statistically significant except of the ROE, ALTMAN Z-SCORE and the IN05 index. these parameters were therefore discarded from the potential regression model as these do not affect the value of the costs of capital.

All selected parameters of final version of our regression model are statistically significant and therefore they affect the value of the costs of capital. The final version of model is in the form below:

$$
\begin{aligned}
Y & =0,14218+0,00445 \cdot \mathrm{LEVERED}+0,00475 \cdot \ln \mathrm{E}+0,00022 \cdot \mathrm{LEVERAGE} \\
& -0,00813 \cdot \ln \mathrm{SIZE}-0,01514 \mathrm{ROA}+0,0175 \cdot \mathrm{DBTA}+0,00604 \cdot \mathrm{ROI}- \\
& -0,00512 \cdot \mathrm{LEGALFORM}-0,00588 \cdot \ln \mathrm{SKNACE}-0,00138 \ln \text { REGION }
\end{aligned}
$$

\subsection{Hypotheses testing}

HYPOTHESIS 1: There is statistical significance of the constructed model of the costs of capital quantification.

To quantify the costs of capital we gradually form four models, including a base one to which we add more proxy variables. By F-test, we test the statistical significance of each model. The interpretation of the test lies in the comparison (4) of the calculated F statistics and critical (table) F statistics. The formulation of the decision rule is:

$$
\begin{aligned}
& \text { 1. If } \left.\mathrm{F}_{\mathrm{df}_{\mathrm{ESS}}^{\mathrm{calc}}}^{\mathrm{cl}}\right\rangle \mathrm{F}_{\alpha ; \mathrm{df}_{\mathrm{ESS}}}^{\mathrm{crit}} \quad \text { rejectHO } \\
& \text { 2. If } \mathrm{P} \text { - value } \mathrm{df}_{\mathrm{ESS}}\langle\alpha \text { rejectHO }
\end{aligned}
$$

Rejection of the null hypothesis always means that the estimated model is statistically significant and a statistically significant relationship between variable $\mathrm{Y}$ and variable $\mathrm{X}$ is confirmed. In the Table 6 we can see the final version of our regression model. At first, we applied the regression function and we got the statistical characteristics of the model. Then we compared the significance level $\alpha$ and p-value of the test (significance F) which proved that the model is statistically significant. 
Table 6: Statistical characteristics of the model

\begin{tabular}{llllll}
\hline ANOVA & & & & \\
& df & SS & MS & F & Significance F \\
\hline Regression & 10 & 3.449678 & 0.344968 & 603.9925 & 0 \\
Residual & 32,116 & 18.34292 & 0.000571 & & \\
Total & 32,126 & 21.7926 & & & \\
\hline
\end{tabular}

Source: Authors

We also get the statistical characteristics of all parameters (Table 7) and comparing the resulting p- value of each parameter and the significance level, we can reject the zero hypothesis in all cases.

Table 7: Statistical characteristics of the parameters

\begin{tabular}{|c|c|c|c|c|c|c|c|c|}
\hline $\begin{array}{l}\text { Parameters of } \\
\text { the model }\end{array}$ & Coeff. & $\begin{array}{l}\text { Standard } \\
\text { Error }\end{array}$ & t Stat & $\mathrm{P}$-value & $\begin{array}{l}\text { Lower } \\
95 \%\end{array}$ & $\begin{array}{l}\text { Upper } \\
95 \%\end{array}$ & P1 & Parameter \\
\hline Constant & 0.142181 & 0.001489 & 95.51283 & 0 & 0.13926 & 0.14509 & H0 rejected & Significant \\
\hline Levered Beta & 0.004455 & 0.00011 & 40.37582 & 0 & 0.00425 & 0.00467 & H0 rejected & Significant \\
\hline Equity value & 0.004746 & 0.00022 & 21.55013 & $2.8 \mathrm{E}-102$ & 0.00431 & 0.00517 & H0 rejected & Significant \\
\hline Leverage & 0.000220 & $8.25 \mathrm{E}-05$ & 2.671906 & 0.007546 & $5.8 \mathrm{E}-05$ & 0.00038 & H0 rejected & Significant \\
\hline Size & -0.008133 & 0.000229 & -35.4427 & $6.1 \mathrm{E}-270$ & -0.00858 & -0.0076 & H0 rejected & Significant \\
\hline ROA & -0.015142 & 0.001628 & -9.2988 & $1.51 \mathrm{E}-20$ & -0.01833 & -0.0119 & H0 rejected & Significant \\
\hline DBTA & 0.017505 & 0.00079 & 22.15418 & $6.1 \mathrm{E}-108$ & 0.01595 & 0.01905 & H0 rejected & Significant \\
\hline ROI & 0.006037 & 0.001616 & 3.73654 & 0.000187 & 0.00287 & 0.00920 & H0 rejected & Significant \\
\hline Legal form & -0.005116 & 0.000353 & -14.5015 & $1.67 \mathrm{E}-47$ & -0.00581 & -0.0044 & H0 rejected & Significant \\
\hline SK NACE & -0.005877 & 0.000223 & -26.3294 & $3.6 \mathrm{E}-151$ & -0.00631 & -0.0054 & $\mathrm{H} 0$ rejected & Significant \\
\hline Region & -0.001385 & 0.000175 & -790555 & $2.75 \mathrm{E}-15$ & $-0,00173$ & -0.0010 & H0 rejected & Significant \\
\hline
\end{tabular}

As we can see in the tables, various calculations and decision criteria clearly confirm that constructed model and its alternatives with the addition of artificial variables are statistically significant. We therefore reject null hypothesis and accept the alternative hypothesis that the constructed model of the costs of capital quantification is statistically significant.

HYPOTHESIS 2: There is a statistically significant relationship between the costs of capital of business entities depending on the legal form.

To test this hypothesis, we use Pearson's chi-squared test based on frequency tables, and we test the null hypothesis that claims that frequencies in individual categories equal to expected theoretical frequencies. If the calculated P-value is lower than the chosen significance level, the null hypothesis is rejected. This means that the difference between the frequency detected in the sample and the expected frequency is too large to be only the result of a random selection, and thus it is statistically significant. If the calculated P-value equals to or is greater than the chosen significance level, the null hypothesis cannot be rejected. This means that the difference between the frequency detected in the sample and the expected frequency can be the result of a random sampling, and thus it is not statistically significant.

H0: There is not a statistically significant relationship between the costs of capital of business entities depending on the legal form.

H1: There is a statistically significant relationship between the costs of capital of business entities depending on the legal form.

The statistical sample is assorted according to the legal form and the costs of capital and the frequency table is set. In the next step we need to calculate theoretical frequencies $T_{i j}$. All calculations were done in Excel using the function CHITEST, which calculates the P-value, which we compare with the chosen level of significance $\alpha$. The calculated P-value $(2.2174 \mathrm{E}$ 224 ) is lower than the chosen significance level $\alpha=0.05$ (same for $\alpha=0.1$ and $\alpha=0.01$ ). This 
means that we reject the null hypothesis and accept the alternative hypothesis - that the costs of capital depend on the legal form of the company.

HYPOTHESIS 3: There is a statistically significant relationship between the costs of capital of business entities depending on the SK NACE classification.

The previous procedure is repeated for the verification of the hypothesis 3. The statistical sample is divided according to the value of the costs of capital and SK NACE classification. We get a table with real frequencies, which is used to calculate theoretical frequencies, and both two tables are put in CHI-function tests. The calculated P-value is then compared with the chosen level of significance $\alpha$ and the decision to accept or reject the null hypothesis is made.

H0: There is no statistically significant relationship between the costs of capital of business entities depending on the SK NACE classification.

H1: There is a statistically significant relationship between the costs of capital of business entities depending on the SK NACE classification.

The calculated P-value ( 0 ) is again lower than the significance level $\alpha$, which means that we reject the null hypothesis - there is a statistical significant relationship between the value of the costs of capital costs and SK NACE classification of business entities.

\section{Discussion}

In this paper we depicted the methods of the cost of capital calculations in the conditions of the Slovak Republic. As the source data for the research we used the balance sheets and profit and loss accounts (year 2014) of those entities which file their statements of finances in the central register managed by the Financial Administration of the Slovak Republic. To form the final model, we select various input variables based on the study of several foreign empirical studies. The aim of this chapter is to compare the theory with our practical results, i.e. to compare the results of international empirical studies with the results of our model. The inspiration for choosing the appropriate parameters in our model were the following foreign studies, which was also used to from an econometric model to calculate the cost of capital:

1. Garcia Lara, J. M., Garia Osma B. and Penalva, F. (2009). Conditional conservatism and cost of capital,

2. Gebhardt, W. R., Lee, C. M. Ch. and Swaminathan, B. (1999). Toward an ex ante cost of capital,

3. Ashbaugh, H., Collins, D. W. and LaFond, R. (2004). Corporate governance and the cost of equity capital,

4. Barth, M. E., Konchitchki, Y. and Landsman, W. R. (2011). Cost of capital and earnings transparency,

5. Botosan, Ch. A. and Plumlee, M. A. (2001). Estimating expected cost of equity capital: A theory-based approach,

6. Byun, H.Y., Kwak, S. K. and Hwang, L.-S. (2008). The implied cost of equity capital and corporate governance.

Authors of these studies perceived the issue of the costs of capital very individually and the choice of parameters of each model was adapted to the specific conditions and the purpose of their research. For this reason, it is practically impossible to apply some of these models in the form as it was proposed abroad, in our economic conditions. We tried to develop a universal model that allows the calculation of the costs of capital of Slovak companies, to which we adapt a choice of determinants. The authors of the foreign studies tested more than 40 different parameters, we chose only those applicable in the Slovak Republic. All these parameters were calculated for all enterprises in our database and we made an econometric analysis, i.e. we 
calculated their statistical significance in the constructed model. We found that the value of the costs of capital is influenced by all variables except for ROE, Altman Z-score and Index IN05. These were therefore withdrawn from our model. Firstly, we created a model which did not contain the qualitative variables (e.g. region, legal form and SK NACE category), but we gradually added them to the model and created three variants of the model. It was found that the three mentioned proxy variables have statistical significance. The relation of the recognized parameters to the value of the costs of capital, which we use in our model based on information from the foreign studies are compared with these models and their empirical researches. Beta factor as an inherent part of the CAPM model for calculating the costs of capital was included in parameters of our model. A positive relationship is visible between the beta factor and the costs of capital value. A plus sign in front of a coefficient related to the beta indicator corresponds with other international studies that included this parameter in the models. We can therefore conclude that if the beta factor of the sector increases / decreases by one unit, the costs of capital of a company will increase / decrease by $0.445 \%$. In foreign studies, market value of equity (its natural logarithm) is usually used in the model or, more often, the ratio of market and book value of equity. It is not easy to determine the market value in Slovak conditions and so we used an alternative variable - natural logarithm of the book value of equity. In our model the parameter has a positive attitude to the total amount of the costs of capital, which partially contradicts the results of foreign studies. Mainly in the study of Botosan and Plumlee (2001) (Expected Estimating Cost of Equity Capital: A Theory-Based Approach) they defined positive or negative sign, depending on the model variant, and in the study of Barth et al. (2011) (Cost of Capital and Earnings Transparency) the coefficient of the value of equity had a minus sign. That difference may be caused by both changing the market value for the book value in our model and also by significantly different economic conditions in Slovak and US markets. As the model indicates if the value of the costs of equity increases / decreases by one unit, the total costs of capital will increase / decrease by $0,475 \%$. The indebtedness (leverage) of the enterprise is a very important indicator of the costs of capital as it expresses the ratio of foreign capital on the total capital structure and that is the reason why it is a part of many econometric models. This parameter in our model has the same sign as in the foreign models, i.e. there is a positive relationship between debt and the costs of capital. If the leverage of the company increases / decreases by one unit, the costs of capital of a company will increase / decrease by $0.02 \%$. It is generally believed that larger enterprises are more stable and less risky which is represented by specific premium for the size of the company and it decreases with increasing size of the company. This means that the larger the company, the lower the costs of capital. This assumption is confirmed also in our research. In international studies as well as in our model the coefficient of the company size has a minus sign. And so if the value of the total company assets (their natural logarithm) increases / decreases by one unit, the costs of capital decreases / increases by $0,813 \%$. We were inspired by Byun et al. (2008) (The Implied Cost of Equity Capital and Corporate Governance Practices) to use ROA in the model. In the mentioned study it had a positive relation to the value of the costs of capital. In our model, however, we achieved a negative sign in front of a coefficient of return on assets, i.e. if the value of ROA increases / decreases the by one unit, the costs of capital will decrease / increase by $1.514 \%$. The ratio of long-term debt capital to total assets (DBTA), was used in the study "Cost of Capital and Earnings Transparency", where the rate had a positive sign, the same results were achieved in our model. Specifically, if the value of DBTA increases / decreases by one unit, the costs of capital of a company will increase / decrease by $1.75 \%$. 


\section{Conclusions}

One of the key areas of the financial management of every company should be the decision on the capital structure of a business enterprise, and thus decision on the proportion of equity and debt capital. This decision is greatly influences by the value of the costs of capital, the company has to bear, and therefore it is necessary for the company to able to quantify these costs. In the countries with developed capital markets, the history of the costs of capital quantification dates in the sixties of the 20th century. All these theories aimed at creating the capital asset pricing model (CAPM), which is still the most widely used method in the equity valuation. All these articles, however, were based on even on Markowitz`s theory of portfolio and risk diversification. The issue of the capital valuation in the Slovak Republic started to be important in the nineties of the 20th century in connection with the transformation of the economy and ownership in companies. After forty years of a mandatory administrative management, not only the book value was important but also the market value started to be used. Almost thirty years delay of activities of Slovak companies in the valuation of capital, compared with companies in developed markets, explains a considerable lag in both theoretical foundations and practical application in the relevant area. The issue of the costs of capital quantification provides a large area for research and its application in practice. The main objective of the paper was to identify significant determinants that affect the value of the costs of capital and use them to form the econometric model enabling the calculation of the costs of capital in the Slovak economic conditions and to create the regression model that would allow the Slovak companies to calculate their cost of capital. Our research was provided with the sample of 32,127 Slovak companies. In parameters selection we were inspired by several studies that were applied in foreign countries. We found out that the significant parameters to be included in the model are levered beta, value of equity, leverage, corporate size, long-term debt capital to total assets, return on assets and on investments, legal form, SK NACE and region. Using the significance F-test and Pearson chi-square test we can claim, that there is a statistically significant relationship between the corporate costs of capital and the legal form and SK NACE classification and we can conclude that there is a statistical significance of the constructed model of the costs of capital quantification. This model can be used to compute the costs of capital of the individual companies in the Slovak economic conditions.

\section{Acknowledgment}

This work was supported by the Slovak Research and Development Agency APVV-140841: Comprehensive Prediction Model of the Financial Health of Slovak Companies.

\section{References}

Amaral, A.M. et al. (2010). Assessing the cost of capital for UPSs in Europe. A practical approach. $17^{\text {th }}$ Centre for Research in Regulated Industries Conference of Postal and Delivery Economics. France, 355-371.

Ashbaugh, H., Collins, D. W. \& Lafond R. (2004). Corporate governance and the cost of equity capital. University of Iowa. 1-54.

Baker, M. \& Wurgler, J. (2002). Market timing and capital structure. The Journal of Finance, 57, 1-32.

Barth, M.E., Konchitchki, Y. \& Landsman, W.R. (2013). Cost of capital and earnings transparency. Journal of Accounting and Economics, 55(2-3), 206-224.

Botosan, CH.A. \& Plumlee, M.A. (2001). Estimating expected cost of equity capital. A theory-based approach. University of Utah, 1-47.

Byun, H.Y., Kwak, S. K. \& Hwang, L.S. (2008). The implied cost of equity capital and corporate governance practices. Asia-Pacific Journal of Financial Studies, 37(1), 139-184. 
Chelley-Steeley, P.L. \& Lambertides, N. (2016). Cost of capital changes, the quality of trading information and market architecture. British Accounting Review, 48(4), 401-414.

Creedy, J. \& Gemmell, N. (2017). Taxation and the user cost of capital. Journal of Economic Surveys, 31(1), 201225.

Damodaran, A. (2006). Damodaran on valuation. $2^{\text {nd }}$ ed., New Jersey, New York: John Wiley \& Sons, Inc.

Drobetz, W. \& Fix, R. (2005). What are the determinants of the capital structure? Evidence from Switzerland. Swiss Journal of Economics and Statistics, 141(1), 71-113.

Dutta, S. \& Nezlobin, A. (2017). Information disclosure, firm growth and the cost of capital. Journal of Financial Economics, 123(2), 415-431.

Fama, E.F. \& French, K.R. (2002). Testing trade-off and pecking order predictions about dividends and debt. The Review of Financial Studies, 15(1), 1-33.

Fernandez, P. (2002). Valuation methods and shareholder value creation. London, United Kingdom: Academic Press.

Fernandez, P. (2013). The equity premium in 150 textbooks. [Online]. Available: http.//ssrn.com labstract $=1473225$.

Frank, M.Z. \& Goyal, V.K. (2003). Testing the pecking order theory of capital structure. Journal of Financial Economics, 67, 217-248.

Garcia Lara, J.M., Garcia Osma, B. \& Penalva, F. (2009). Conditional conservatism and cost of capital. Madrid. [Online]. Available: http.//ssrn.com/abstract=1544307.

Gebhardt, W.R., Charles, M.C. \& Swaminathan, B. (1999). Toward an ex ante cost-of-capital. Cornell University. Ithaca, NY. [Online]. Available: http.//papers.ssrn.com/sol3/papers.cfm?abstract_id=145928.

Hovakimian, A., Opler, T. \& Titman, S. (2001). The debt - equity choice. The Journal of Financial and Quantitative Analysis, 36(1), 1-24.

Jensen, M.C. \& Meckling, W.H. (1976). Theory of the firm. Managerial behavior, agency costs and ownership structure. Journal of Financial Economics, 3(4).

Johnstone, D. (2016). The effect of information on uncertainty and the cost of capital. Contemporary Accounting Research, 33(2), 752-774.

Kislingerova, E. (2001). Oceňování podniku. $2^{\text {nd }}$ ed. Praha, Czech Republic: C. H. Beck.

Kraus, A. \& Litzenberger, R.H. (1973). A state-preference model of optimal financial leverage. The Journal of Finance, 28, 911-922.

Lambert, R.A., Leuz, C. \& Verrecchia, R.E. (2012). Information asymmetry, information precision and the cost of capital. Review of Finance, 16(1), 1-29.

Lambert, R.A., Leuz, C. \& Verrecchia, R.E. (2007). Accounting information, disclosure and the cost of capital. Journal of Accounting Research, 45(2), 385-420.

Levi, Y. \& Welch, I. (2017). Best practices for cost of capital estimates. Journal of Financial and Quantitative Analysis, 52(2), 427-463.

Memon, P.A., Rohani, R. \& Ghazali, Z.B. (2014). Firm and macroeconomic determinants of debt. Pakistan evidence. Global Conference on Business \& Social Science. Kuala Lumpur, Malaysia, 200-207.

Michalak, A. (2016). The cost of capital in the effectiveness assessment of financial management in a company. Oeconomia Copernicana, 7(2), 317-329.

Modigliani, F. \& Miller, H.M. (1958). The cost of capital, corporation finance and the theory of investment. The American Economic Review, vol. 48, no. 3, pp. 261-297.

Mokhova, N. \& Zinecker, M. (2013). Macroeconomic factors and corporate capital structure. Contemporary Issues in Business, Management and Education, 110, 530-540.

Murray, Z.F. \& Vidhan, K.G. (2003). Testing the pecking order theory of capital structure. Journal of Financial Economics, 67, 217-248.

Myers, S. (2001). Capital structure. Journal of Economic Perspectives, 15, 81-102.

Myers, S. \& Majluf, N. (1984). Corporate financing and investment decisions when firms have information that investors do not have. Journal of Financial Economics, 13, 187-221.

Ogier, T., Rugman, J. \& Spicer, L. (2004). The real cost of capital. Harlow, England: Pearson Education Limited.

Olson, G.T. \& Pagano, M.S. (2017). The empirical average cost of capital. A new approach to estimating the cost corporate funds. Journal of Applied Corporate Finance, 29(3), 101-+.

Plumlee, M.A. (2016). Discussion of "The effect of information on uncertainty and the cost of capital". Contemporary Accounting Research, 33(2), 775-782.

Rajan, R. \& Zingales, L. (1995). What do we know about capital structure? Some evidence from international data. Journal of Finance, 50(5), 1421 - 1460.

Salim, M. \& Yadav, R. (2012). Capital structure and firm performance. Evidence from Malaysian listed companies. Procedia - Social and Behavioral Sciences, 65, 156-166. 
Serghiescu, L. \& Vaidean, V.L. (2014). Determinant factors of the capital structure of a firm - an empirical analysis. Emerging Markets Queries in Finance and Business, 32, 1314-1322.

Shyam-Sunder, L. \& Myers, S. (1999). Testing static tradeoff against pecking order models of capital structure. Journal of Financial Economics, 51(2), 219-244.

Suto, M. \& Tekehara, H. (2017). CSR and cost of capital. Evidence from Japan. Social Responsibility Journal, 13(4), 798-816.

Titman, S. \& Wessels, R. (1988). The determinants of capital structure choice. The Journal of Finance, 43(1), 119.

Viviani, J.L. (2008). Capital structure determinants. An empirical study of French companies in the wine industry. International Journal of Wine Business Research, 20(2), 171-194.

Voth, H.J. (2003). Convertibility, currency controls and the cost of capital in Western Europe 1950-1999. International Journal of Finance \& Economics, 8(3), 255-276.

Voth, H.J. (2002). Stock market liberalization, the cost of capital and economic growth in postwar Europe. Journal of Economic History, 62(2), 575-575. 